CELLULOSE CHEMISTRY AND TECHNOLOGY

\title{
HYPSIZYGUS MARMOREUS - \\ A NOVEL POTENT DEGRADER OF LIGNOCELLULOSE RESIDUES
}

\author{
MILICA GALIĆ, MIRJANA STAJIĆ and JASMINA ĆILERDŽIĆ \\ University of Belgrade, Faculty of Biology, Takovska 43, 11000 Belgrade, Serbia \\ ๔ Corresponding author: Jasmina Ćilerdžić, simonicj@bio.bg.ac.rs
}

Received June 4, 2020

Hypsizygus marmoreus is an edible and medicinal commercially cultivated mushroom, whose ligninolytic potential is still insufficiently known. Therefore, the goals of this study were to profile its Mn-oxidizing peroxidases and laccases activity and its potential to depolymerize common agro-forestry residues. Raspberry and blackberry sawdust induced the production of highly active laccases $\left(26006.83 \mathrm{U} \mathrm{L}^{-1}\right.$ and $17576.79 \mathrm{U} \mathrm{L}^{-1}$, respectively), while the activity peaks of Mn-dependent peroxidase $\left(134.47 \mathrm{U} \mathrm{L}^{-1}\right)$ and $\mathrm{Mn}$-independent peroxidase $\left(184.40 \mathrm{U} \mathrm{L}^{-1}\right)$ were recorded on plum sawdust and wheat straw, respectively. The pretreatment of corn stalks resulted in the highest lignin removal (57.15\%), while the highest lignin/cellulose removal ratio (selectivity) was noted on oak sawdust (17.69). The maximal (20\%) and the minimal $(8.30 \%)$ dry matter loss were obtained for corn stalks and oak sawdust, respectively. The presented results showed the exceptional potential of the ligninolytic system of $H$. marmoreus HAI 605 and the possibility of its application in numerous biotechnological processes.

Keywords: agro-forestry residues, Hypsizygus marmoreus, ligninolytic enzymes, lignocelluloses depolymerization

\section{INTRODUCTION}

One of the main trends of modern society is to provide sufficient amounts of high-value food and energy due to the geometric progression of the human population and intensive industrial and technological development. However, it leads to great pressure on natural resources and ecosystems in general, and therefore there is a need for the creation of environmentally friendly procedures for food and energy production, aiming to preserve the integrity of ecosystems. ${ }^{1}$ Nowadays, numerous studies are focused on the definition of conditions for the most efficient usage of lignocellulosic wastes, which are produced annually in huge quantities, but are not used, despite their great potential, and mostly improperly deposited or combusted, releasing $\mathrm{CO}_{2}$ and other pollutants, and adversely affecting the environment. ${ }^{2-4}$ These wastes are mainly generated in agriculture and forestry, in the food industry as well as municipal wastes (yard trimmings and wood), and could be excellent renewable sources for the production of not only feed and high nutritional value food (such as mushroom fruiting bodies), but also biofuels, chemicals, and industry-related products. ${ }^{5}$
According to the estimation of the International Renewable Energy Agency (IRENA), ${ }^{6}$ the consumption of renewable energy resources in the European Union will increase from $17 \%$ in 2015 to $34 \%$ in 2030, and biomass will remain a key energy source. Nowadays, bioethanol, one of the most widely used alternative energy sources, is mainly produced by fermentation of dominant crops waste, i.e. rice, corn, or wheat residues. ${ }^{7}$ However, numerous challenges lie ahead for producers, such as what plant residues should be used, how to economically and primarily environmentally friendly degrade lignin, the most recalcitrant molecule in the plant cell wall, etc. Preference should be given to biomass that could not be used as food/feed and has a more favorable energy input/output ratio, as well as to biological delignification. ${ }^{1,8}$ The most efficient participants in pretreatment, the first phase in the process of bioethanol production, are white-rot fungi, due to their remarkable capacity to produce ligninolytic enzymes, which oxidize lignin and facilitate access to holocellulose. ${ }^{9}$ However, the efficiency of these enzymes varies from species to species, 
even from strain to strain, and depends on cultivation conditions. $^{10-12}$ Therefore, the most effective and selective lignin remover and optimized conditions for the production of its most active enzyme isoforms should be found.

Hypsizygus marmoreus (Peck) Bigelow is an edible and medicinal mushroom, which is cultivated commercially, especially in East Asia. ${ }^{13}$ This species was the object of numerous studies focused on its nutritional value, bioactive compounds, and healthcare functions, while its potential to degrade lignin has only been the topic of several researches. ${ }^{14-17}$ Therefore, the objectives of this study were to determine the Mnoxidizing peroxidases and laccases activity profile in $H$. marmoreus cultivated on eight common European agro-forestry residues, as well as its capacity to delignify selected plant materials.

\section{EXPERIMENTAL}

\section{Organism and growth conditions}

The culture of the studied Hipsizygus marmoreus HAI 605 was obtained from the Institute of Evolution, University of Haifa, Israel (HAI), and maintained on Malt agar medium in the culture collection of the Institute of Botany, Faculty of Biology, University of Belgrade.

The inoculum was obtained by inoculation of synthetic glucose/ $\mathrm{NH}_{4} \mathrm{NO}_{3}$ /yeast extract medium with mycelium of 7-day old culture, incubation at room temperature on a rotary shaker for 7 days, washing the harvested biomass with sterile distilled water $\left(\mathrm{dH}_{2} \mathrm{O}\right)$, and its homogenization with $\mathrm{dH}_{2} \mathrm{O}$ in a laboratory blender (Waring, USA). ${ }^{11}$ The inoculum, in the amount of $3.0 \mathrm{~mL}$, was used for inoculation of $6.0 \mathrm{~g}$ of tested agro-forestry residue (apple-, blackberry-, grapevine-, oak -, plum-, and raspberry sawdust, corn stalks, and wheat straw) soaked with $30.0 \mathrm{~mL}$ of the modified synthetic medium (without glucose). Solid-state cultivation was carried out in $250 \mathrm{~mL}$ flasks at $25{ }^{\circ} \mathrm{C}$ for 21 days.

\section{Assays of enzyme activity and total protein production}

The ligninolytic enzymes were extracted by the method of Ćilerdžić et al., ${ }^{11}$ i.e. by sample stirring with $50.0 \mathrm{~mL}$ of $\mathrm{dH}_{2} \mathrm{O}$ at $4{ }^{\circ} \mathrm{C}$ for $10 \mathrm{~min}$. The supernatant obtained after extract centrifugation $\left(4{ }^{\circ} \mathrm{C}, 3000 \mathrm{rpm}\right.$, $15 \mathrm{~min}$ ) was used for measurement of the activity of $\mathrm{MnP}$-oxidizing peroxidases [Mn-dependent peroxidase (MnP, EC 1.11.1.13) and Mn-independent peroxidase (MnIP, EC 1.11.1.16)] and laccase (EC 1.10.3.2), as well as total protein content, by a spectrophotometer (CECIL CE2501 (BioQuest), UK).

The activities of Mn-oxidizing peroxidases and laccases were determined by using $3 \mathrm{mM}$ phenol red $\left(\varepsilon_{610}=22000 \mathrm{M}^{-1} \mathrm{~cm}^{-1}\right)$ and 2,2'-azino-bis-[3- ethyltiazoline-6-sulfonate] (ABTS) $\left(\varepsilon_{436}=29300 \mathrm{M}^{-1}\right.$ $\mathrm{cm}^{-1}$ ), respectively. ${ }^{11}$ Enzymatic activity was expressed in $\mathrm{U} \mathrm{L}^{-1}$, and the activity of $1 \mathrm{U}$ presents the amount of enzyme that transforms $1.0 \mu \mathrm{mol}$ of substrate per min.

The total protein content was determined by the method of Silva et al., ${ }^{18}$ utilizing Bradford's reagent and bovine serum albumin as standard, and expressed in $\mathrm{mg} \mathrm{mL}^{-1}$. The value was used for the definition of the specific enzyme activity $\left(\mathrm{U} \mathrm{mg}^{-1}\right)$, an indicator of enzyme purity.

\section{Determination of lignin, cellulose, and hemicellulose contents}

The loss of substrate dry matter (\%) was determined by the equation $(\mathrm{M} i-\mathrm{M} f) / \mathrm{M} i \mathrm{x} 100$, where $\mathrm{M} i$ represents the initial lignocellulosic mass and $\mathrm{M} f-$ the mass after fermentation.

The contents of lignin, cellulose, and hemicelluloses were determined by modified methods of Kirk and Obst, ${ }^{19}$ and Van Soest et al. ${ }^{20}$ A dried ground sample $(1.0 \mathrm{~g})$ was treated with a neutral detergent $/ \mathrm{Na}_{2} \mathrm{SO}_{3}$ mixture under refluxing conditions to remove soluble sugars, proteins, lipids, and vitamins. The obtained biomass presented neutral detergent fibers (NDF). Acidic detergent fibers (ADF) were obtained by the treatment of the samples with acidic detergent solution, and the difference between NDF and ADF represented the hemicelluloses amount. The lignin content (LC), expressed as the percentage of quantity present in the initial sample, was defined after sample incubation with $72 \% \mathrm{H}_{2} \mathrm{SO}_{4}$ at $30{ }^{\circ} \mathrm{C}$ and its hydrolysis at $120{ }^{\circ} \mathrm{C}$. The cellulose content was calculated as the difference between ADF and LC.

The selectivity index, i.e. the ratio between the amounts of removed lignin and cellulose, was used as an indicator of selectivity in lignin degradation.

\section{Statistical analyses}

All the experiments were done in three replicates and the results were expressed as mean \pm standard error. Assaying any significant differences among means was performed by one-way analysis of variance (ANOVA) and Tukey's test, using STATISTICA, version 6.0 (StatSoft, Inc., Tulsa, USA). Statistical significance was declared at $p<0.05$.

\section{RESULTS AND DISCUSSION}

The majority of the tested agro-forestry residues stimulated the production of laccase and Mn-oxidizing peroxidases by Hypsizygus marmoreus HAI 605 (Fig. 1). The synthesized laccase isoforms were characterized by extremely high activity, especially those produced during the fermentation of raspberry sawdust $\left(26006.83 \mathrm{U} \mathrm{L}^{-}\right.$ $\left.{ }^{1}\right)$. Blackberry-, grapevine- and oak sawdusts were also good inducers of laccase activity (17576.79 $\mathrm{U} \mathrm{L} \mathrm{L}^{-1}, 13139.93 \mathrm{U} \mathrm{L}^{-1}$, and $9914.67 \mathrm{U} \mathrm{L}^{-1}$, 
respectively), while apple- and plum sawdusts and wheat straw inhibited the synthesis of this enzyme.

Contrary to laccase, the activities of the synthesized Mn-oxidizing peroxidases were remarkably lower (Fig. 1). $H$. marmoreus produced more active isoforms of MnIP than of MnP. The most favorable substrate for MnIP activity was wheat straw $\left(184.40 \quad \mathrm{U}^{-1}\right)$; grapevine-, plum- and blackberry sawdusts were also good inducers of the activity $\left(126.89 \mathrm{U} \mathrm{L}^{-1}\right.$, 123.11 $\mathrm{U} \mathrm{L}^{-1}$, and $109.85 \mathrm{U} \mathrm{L}^{-1}$, respectively), while apple sawdust and corn stalks inhibited the synthesis of the enzyme. In the case of MnP, plum sawdust was the best stimulator of the activity (134.47 $\mathrm{U} \mathrm{L}^{-1}$ ), and further, the activity gradually decreased in the following order: $62.50 \mathrm{U} \mathrm{L}^{-1}$ (corn stalks) > 56.82 $\mathrm{U} \mathrm{L}^{-1}$ (blackberry sawdust) > $35.98 \mathrm{U} \mathrm{L}^{-1}$ (raspberry sawdust) $>28.41 \mathrm{U} \mathrm{L}^{-1}$ (grapevine sawdust) $>15.10 \mathrm{U} \mathrm{L}^{-1}$ (wheat straw). Apple sawdust also inhibited the synthesis of MnP.

The agro-forestry residues used in the study also affected the protein production and, consequently, the specific activities of the enzymes. The highest protein content was noted after corn stalk fermentation $\left(3.8 \mathrm{mg} \mathrm{mL}^{-1}\right)$ and the lowest - after apple sawdust fermentation (0.6 $\left.\mathrm{mg} \mathrm{mL}{ }^{-1}\right)$. A significant value of specific enzyme activities was noted for laccase produced during $H$. marmoreus cultivation on plum sawdust (22.34 $\mathrm{U} \mathrm{mg}^{-1}$ ), while specific activities of Mn-oxidizing peroxidases were insignificant, less than $1.0 \mathrm{U}$ $\mathrm{mg}^{-1}$.

Owing to the ability to synthesize the mentioned enzymes, $H$. marmoreus HAI 605 was a good degrader of lignocellulosic residues. Namely, it caused the loss of corn stalk dry matter of even $20.00 \%$, the reduction was $5-7 \%$ lower after the fermentation of raspberry-, apple-, grapevine- blackberry- and plum sawdust, and wheat straw, while this percentage was the smallest in oak sawdust (8.30\%) (Table 1).

The type of plant residues also affected the enzymes' efficiency to cause degradation of lignocellulosic polymers. After 21 days of fermentation, the maximal reduction of lignin content was noted in corn stalks (57.15\%), slightly lower in apple sawdust $(49.12 \%)$, and the lowest in plum sawdust (5.72\%) (Table 1). However, H. marmoreus HAI 605 was not only a highly effective delignifier of corn stalks and apple sawdust, but also a depolymerizer of hemicelluloses (24.89\% and $28.74 \%$, respectively) and cellulose (33.36\% and $24.94 \%$, respectively), which was reflected in low selectivity indices (1.71 and 1.97 , respectively).

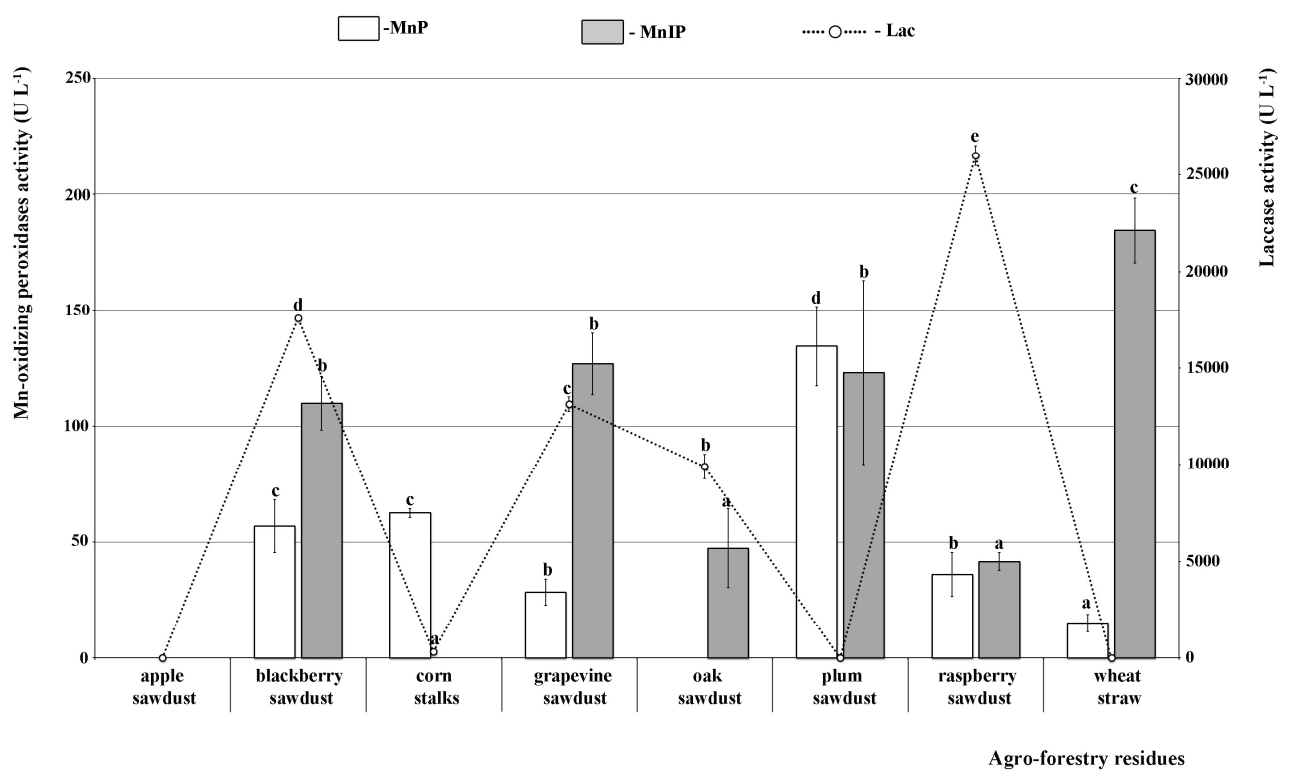

Figure 1: Effect of agro-forestry residues on activity of Mn-dependent peroxidase, Mn-independent peroxidase and laccase produced by Hypsizygus marmoreus HAI 605 during solid-state cultivation 
MILICA GALIĆ et al.

Table 1

Extent of dry mass loss and depolymerisation of selected lignocellulose residues by Hypsizygus marmoreus HAI 605

\begin{tabular}{|c|c|c|c|c|c|c|c|c|c|c|}
\hline \multirow{2}{*}{$\begin{array}{l}\text { Agro- } \\
\text { forestry } \\
\text { residues }\end{array}$} & \multirow{2}{*}{$\begin{array}{l}\text { Studied } \\
\text { species }\end{array}$} & \multirow{2}{*}{$\begin{array}{c}\text { Sample } \\
\text { weight } \\
\text { (g) }\end{array}$} & \multicolumn{3}{|c|}{$\begin{array}{l}\text { Fiber composition of samples } \\
(\mathrm{mg})\end{array}$} & \multirow{2}{*}{$\begin{array}{c}\text { Dry } \\
\text { matter } \\
\text { loss }(\%)\end{array}$} & \multicolumn{3}{|c|}{$\begin{array}{c}\text { Extent of polymer degradation } \\
(\%)\end{array}$} & \multirow{2}{*}{$\begin{array}{l}\text { Selectivity } \\
\text { index }\end{array}$} \\
\hline & & & Lignin & Cellulose & Hemicelluloses & & Lignin & Cellulose & Hemicelluloses & \\
\hline \multirow{2}{*}{$\begin{array}{l}\text { Apple } \\
\text { wood } \\
\text { sawdust }\end{array}$} & Control & 6.00 & 1158.00 & 2808.00 & 1176.00 & I & 1 & I & I & I \\
\hline & HAI 605 & 5.08 & 589.16 & 2107.79 & 838.04 & 15.33 & 49.12 & 24.94 & 28.74 & 1.97 \\
\hline \multirow{2}{*}{$\begin{array}{l}\text { Blackberry } \\
\text { sawdust }\end{array}$} & Control & 6.00 & 1218.00 & 2712.00 & 1038.00 & I & I & I & I & I \\
\hline & HAI 605 & 5.21 & 770.78 & 1963.42 & 843.70 & 13.17 & 36.72 & 27.60 & 18.72 & 1.33 \\
\hline \multirow{2}{*}{$\begin{array}{l}\text { Corn } \\
\text { stalks }\end{array}$} & Control & 6.00 & 594.00 & 2796.00 & 1860.00 & I & I & I & I & I \\
\hline & HAI 605 & 4.80 & 254.51 & 1863.18 & 1397.38 & 20.00 & 57.15 & 33.36 & 24.89 & 1.71 \\
\hline \multirow{2}{*}{$\begin{array}{l}\text { Grapevine } \\
\text { sawdust }\end{array}$} & Control & 6.00 & 1421.41 & 2652.00 & 887.08 & I & I & I & I & I \\
\hline & HAI 605 & 5.15 & 963.24 & 2420.97 & 710.84 & 14.15 & 32.23 & 8.17 & 19.87 & 3.94 \\
\hline \multirow{2}{*}{$\begin{array}{l}\text { Oak } \\
\text { sawdust }\end{array}$} & Control & 6.00 & 1530.00 & 2808.00 & 1159.00 & I & I & I & I & I \\
\hline & HAI 605 & 5.50 & 1034.75 & 2757.50 & 891.65 & 8.30 & 32.37 & 1.83 & 23.13 & 17.69 \\
\hline \multirow{2}{*}{$\begin{array}{l}\text { Plum } \\
\text { sawdust }\end{array}$} & Control & 6.00 & 1837.49 & 2544.00 & 1368.00 & I & I & I & I & I \\
\hline & HAI 605 & 5.23 & 1732.45 & 1648.71 & 743.23 & 12.62 & 5.72 & 35.19 & 45.67 & 0.16 \\
\hline \multirow{2}{*}{$\begin{array}{l}\text { Raspberry } \\
\text { sawdust }\end{array}$} & Control & 6.00 & 1200.00 & 2160.00 & 1308.00 & I & I & I & I & I \\
\hline & HAI 605 & 5.09 & 951.46 & 1897.82 & 803.90 & 15.20 & 20.71 & 12.14 & 38.54 & 1.71 \\
\hline \multirow{2}{*}{$\begin{array}{l}\text { Wheat } \\
\text { straw }\end{array}$} & Control & 6.00 & 666.00 & 2418.00 & 1692.00 & I & I & I & I & I \\
\hline & HAI 605 & 5.13 & 554.26 & 2217.02 & 1339.45 & 14.50 & 16.78 & 8.31 & 20.84 & 2.02 \\
\hline
\end{tabular}


The highest selectivity index (17.69) was noted after oak sawdust fermentation, indicating a significant reduction of lignin content $(32.37 \%)$ and cellulose loss of only $1.83 \%$. Likewise, this species showed a significantly high delignification potential during cultivation on corn stalks $(57.15 \%)$, apple sawdust $(49.12 \%)$, blackberry sawdust $(36.72 \%)$, and grapevine sawdust $(32.23 \%)$. However, these substrates also induced the synthesis of highly active forms of holocellulases, causing cellulose depolymerization and low selectivity indices (1.33-3.94). The lowest selectivity index, of only 0.16 , was obtained for plum sawdust. Namely, during cultivation on this residue, the enzymatic system of $H$. marmoreus was more efficient in cellulose and, especially, hemicellulose removal $(35.19 \%$ and $45.67 \%$, respectively), in comparison with lignin, of which only $5.72 \%$ was degraded (Table 1).

The noted positive correlation between primarily laccase activity and the extent of lignin removal from some tested plant residues during solid-state fermentation indicated that laccase was a key enzyme in lignin mineralization. On the contrary, Songulashvili et al. ${ }^{15}$ noted that submerged cultivation of this species on mandarin peels and residues of ethanol production from wheat grain was not favorable for the synthesis of laccase and especially $\mathrm{MnP}$, whose activity was not even detected. On the other hand, Xu et al. ${ }^{16}$ reported the production of $\mathrm{MnP}$ with significant activity $\left(\sim 250 \mathrm{U} \mathrm{L}^{-1}\right)$ by this species after only 7day long submerged fermentation of malt-yeast extract-peptone-glucose-bran extract, and thus emphasized that these two groups of enzymes (peroxidases and oxidases) have a synergistic effect on lignin degradation, namely at the beginning of the process, peroxidases possess a key role in delignification, while over the time this role is taken by oxidases, i.e. laccases. However, in some cases, solid cultivation also caused the absence of some ligninolytic enzymes, for example, Hypsizygus tessulatus did not produce laccase in the solid fermentation of wheat straw. ${ }^{11}$ Based on sequencing and characterization of the gene responsible for laccase synthesis in $H$. marmoreus (lccl), Zhang et al. ${ }^{17}$ proposed that lignocellulosic materials regulate the synthesis of the enzyme on the transcriptional level. Generally, H. marmoreus, together with Pleurotus spp., makes a group of highly potential laccase producers. Namely, Dong et al. ${ }^{21}$ and Ćilerdžić et $a l .^{22}$ detected remarkably high laccase activity
(35000 $\mathrm{U} \mathrm{L}^{-1}$ ) synthesized after a few weeks of sugarcane bagasse fermentation by $P$. ostreatus and oak sawdust fermentation by $P$. pulmonarius. In comparison with other white-rot species, $H$. marmoreus had multi-fold stronger potential for the production of highly active laccase isoforms. Thus, Auricularia auricula synthetized a low active laccase isoform only in blackberry sawdust based medium, ${ }^{12}$ while this enzyme was not produced by Ganoderma lucidum during wheat straw solid-state fermentation. ${ }^{11}$

According to the high capacity of laccase production, $H$. marmoreus was a significantly stronger delignifier than numerous fungal species. Thus, H. marmoreus was a better and more selective degrader of corn residues than Irpex lacteus and Phanerochaete chrysosporium. ${ }^{22,23}$ Namely, I. lacteus caused the loss of $37.6 \%$ corn stalk lignin, but after as many as 42 days of pretreatment, while $\sim 50 \%$ of corn stover lignin was degraded by $P$. chrysosporium after 30 days. Although $H$. marmoreus showed a similar potential of oak sawdust delignification to that of Ganoderma applanatum strain studied by Ćilerdžić et al., ${ }^{24}$ its selectivity was remarkably higher, i.e. in contrast with H. marmoreus, G. applanatum simultaneously mineralized a high percentage of both lignin and holocellulose. However, Hypsizygus tessulatus was a better delignifier than $H$. marmoreus HAI 605 , but the degradation selectivity was similar.

\section{CONCLUSION}

Despite the studies already perfomed on Hypsizygus marmoreus, these results demonstrate for the first time high diversity in the profile of ligninolytic enzymes produced on until now untested agro-forestry residues. H. marmoreus HAI 605 is proven as a highly potent producer of enzymes and consequently a remarkable delignifier of the selected residues, which makes it a promising participant for various biotechnological processes. The demonstrated high selectivity for lignin over holocellulose degradation by $H$. marmoreus, in comparison to other wood rot fungi, is one more contribution of the present research. According to data from the Food and Agricultural Organization, Serbia is a significant global producer of raspberry, plum, blackberry, apple, and grape, and their residues could be efficiently biotransformed into various value-added products. This offers special economical and ecological importance to our results. Finally, H. marmoreus HAI 605 deserves 
further investigations, aiming to introduce new biotechnological applications.

ACKNOWLEDGEMENTS: This study was carried out under project No. 173032, financially supported by the Ministry of Education, Science and Technological Development of the Republic of Serbia.

\section{REFERENCES}

1 M. N. Kumar, R. Ravikumar, S. Thenmozhi, M. R. Kumar and M. K. Shankar, Waste Biomass Valorif., 10, 1693 (2019), https://doi.org/10.1007/s12649-0170177-6

2 C. Güler, H. I. Sahin and S. Yeniay, Wood Res., 61, 299

http://www.woodresearch.sk/wr/201602/13.pdf

(2016),

3 A. Enghiad, D. Ufer, A. M. Countryman and D. D. Thilmany, Int. J. Agron., Article ID 3931897 (2017), https://doi.org/10.1155/2017/3931897

4 Food and Agriculture Organization Corporate Statistical Database, http://www.fao.org/faostat

5 Y. Y. Deng, M. Koper, M. Haigh and V. Dornburg, Biomass Bioenerg., 74, $253 \quad$ (2015), https://doi.org/10.1016/j.biombioe.2014.12.003

6 International Renewable Energy Agency, Renewable Energy Prospects for the European Union, 2018

7 S. H. Ghaffar, M. Fan and B. McVicar, Ind. Crop. Prod., 77, 262 (2015), https://doi.org/10.1016/j.indcrop.2015.08.060

8 F. Q. Wang, H. Xie, W. Chen, E. T. Wang, F. G. Du et al., Bioresour. Technol., 144, 572 (2013), https://doi.org/10.1016/j.biortech.2013.07.012

9 C. Sánchez, Bioetchnol. Adv., 27, 185 (2009), https://doi.org/10.1016/j.biotechadv.2008.11.001

10 J. Ćilerdžić, M. Stajić and J. Vukojević, Bioresources, $\quad 9, \quad 5577 \quad$ (2014), https://doi.org/10.15376/biores.9.3.5577-5587

11 J. Ćilerdžić, M. Galić, J. Vukojević, I. Brčeski and M. Stajić, BMC Plant Biol., 17, 249 (2017), https://doi.org/10.1186/s12870-017-1196-y
12 M. Galić, M. Stajić, J. Vukojević and J. Ćilerdžić, Cellulose Chem. Technol., 54, 179 (2020), https://doi.org/10.35812/CelluloseChemTechnol.2020. 54.20

${ }^{13}$ E. B. Jung, J. H. Jo and S. M. Cho, J. Kor. Soc. Food Sci. Nutr., 37, $1395 \quad$ (2008), https://doi.org/10.3746/jkfn.2008.37.11.1395

14 Y. Amano, K. Nishizawa, R. Tokoo, T. Matsuzawa and T. Kanda, J. Jpn. Wood Res. Soc. (Japan), 38, 411 (1992)

15 G. Songulashvili, V. Elisashvili, S. P. Wasser, E. Nevo and Y. Hadar, Enzyme Microb. Tech., 41, 57 (2007), https://doi.org/10.1016/j.enzmictec.2006.11.024

16 J. Z. Xu, J. L. Zhang, K. H. Hu and W. G. Zhang, Microb. Biotechnol., 6, $241 \quad$ (2013), https://doi.org/10.1111/j.1751-7915.2012.00365.x 17 J. Zhang, H. Chen, M. Chen, A. Ren, J. Huang et al., Microb. Res., 179, 54 (2015), https://doi.org/10.1016/j.micres.2015.06.005

18 C. M. M. S. Silva, S. I. Melo and R. P. Oliveira, Enzyme Microb. Tech., 37, 324 (2005), https://doi.org/10.1016/j.enzmictec.2004.12.007

19 T. K. Kirk and J. R. Obst, in "Methods in Enzymology", vol. 161: "Lignin Determination", edited by S. P. Colowick and N. O. Kaplan, Academic Press Inc., 1988, pp. 87-101

20 P. V. Van Soest, J. B. Robertson and B. A. Lewis, J. Dairy Sci., 74, $3583 \quad$ (1991), https://doi.org/10.3168/jds.S0022-0302(91)78551-2

${ }_{21}$ X. Q. Dong, J. S. Yang, N. Zhu, E. T. Wang and H. L. Yuan, Bioresour. Technol., 131, 443 (2013), https://doi.org/10.1016/j.biortech.2012.12.182

${ }^{22}$ M. Galić, M. Stajić and J. Ćilerdžić, Int. Biodeter. Biodegrad., (2020), (in press)

${ }^{23}$ W. Du, H. Yu, L. Song, J. Zhang, C. Weng et al., Biotechnol. Biofuels, 4, 37 (2011), https://doi.org/10.1186/1754-6834-4-37

24 B. C. Saha, N. Qureshi, G. J. Kennedy and M. A. Cotta, Int. Biodeter. Biodegrad., 109, 29 (2016), https://doi.org/10.1016/j.ibiod.2015.12.020

25 J. Ćilerdžić, M. Stajić and J. Vukojević, Int. Biodeter. Biodegrad., 114, 39 (2016), https://doi.org/10.1016/j.ibiod.2016.05.024 